\title{
Perancangan Sistem Informasi Tugas Akhir Jurusan Teknik Industri Universitas Islam Negeri Sultan Syarif Kasim Riau
}

\author{
Nofirza, Harpito, Ekie Gilang Permata, Melfa Yola, Ismu Kusumanto, Muhammas Arief Syarisky \\ Jurusan Teknik Industri, Fakultas Sains dan Teknologi, UIN Sultan Syarif Kasim Riau \\ Jl. HR. Soebrantas No.155 Simpang Baru, Panam, Pekanbaru, 28293 \\ Email : arief.syarisky@yahoo.co.id
}

\begin{abstract}
Abstrak
Prosedur pengurusan tugas akhir yang ada dijurusan teknik industri universitas islam negeri sultan syarif saat ini masih manual sehingga prosedur menjadi tidak efektif dan efisien. Tujuan penelitian yaitu merancang sistem informasi tugas akhir jurusan teknik industri universitas islam negeri sultan syarif kasim riau yang ergonomi dan sesuai kebutuhan mahasiswa serta koordinator TA. Metode pengumpulan data didapatkan dengan melakukan observasi dan wawancara ke koordinator TA jurusan teknik industri sehingga didapatkan flowchart prosedur pengurusan tugas akhir. Pengolahan data diawali dengan evaluasi kebutuhan mahasiswa dan kemudian merancang aplikasi antar muka atau user interface dengan aturan display, mengatur penggunaan warna, selain itu juga melakukan perhitungan huruf dan juga melakukan pengujian sistem. Hasil perancangan sistem yang kemudian diujikan ke mahasiswa dan memperoleh hasil bahwa, rata-rata mahasiswa setuju dan sangat mendukung dengan adanya sistem informasi ini. Hasil penelitian ini berupa sistem informasi tugas akhir jurusan teknik industri yang bisa diakses secara online dan diharapkan dapat membantu mahasiswa dan koordinator dalam menyelesaikan prosedur pengurusan tugas akhir dijurusan Teknik Industri.
\end{abstract}

Kata Kunci: Sistem Informasi Tugas Akhir, Display, Prosedur Tugas Akhir

\section{Pendahuluan}

Perkembangan teknologi informasi menyelesaikan pekerjannya. Dengan teknologi informasi, manusia dapat menghemat waktu, tenaga, dan biaya. Salah satu contoh penerapan teknologi informasi adalah di dalam dunia pendidikan. Teknologi informasi juga membantu dunia pendidikan menjadi lebih baik, lebih maju, dan lebih modern, dimana telah banyak perangkat-perangkat pendukung untuk pendidikan seperti software, website, portalportal pendidikan yang dapat digunakan untuk memperkaya ilmu para penggunanya. Salah satu contoh penerapan teknologi informasi di dunia pendidikan adalah sistem informasi.

Keberhasilan sebuah instansi yang bergerak di bidang pendidikan, bukan hanya diperhitungkan dari ketepatan dan banyaknya lulusan yang dihasilkan, melainkan juga dari bagaimana instansi tersebut mengelola berbagai data yang ada untuk mendapatkan suatu informasi yang diperlukan oleh civitas akademika instansi yang bersangkutan. Informasi yang berkualitas adalah informasi yang dapat disajikan secara relevan, akurat, dan tepat waktu. Sehingga pihak yang menerima akan dapat memanfaatkan informasi tersebut sesuai harapan.

Universitas Islam Negri Sultan Syarif Kasim Riau atau sering disebut dengan Uin Suska Riau merupakan salah satu kampus Madani yang berada dikota Pekanbaru Provinsi Riau. Salah satu jurusan yang ada di Uin Suska Riau ialah Teknik Industri, dimana Teknik Industri ini merupakan salah satu jurusan yang ada di Fakultas Sains dan Teknologi. Jurusan Teknik Industri merupakan jurusan dengan jenjang pendidikan Strata-1, yang memiliki berbagai macam mata kuliah umum. Selain menyelesaikan mata kuliah yang ada, salah satu syarat kelulusan di Teknik Industri Uin Suska ialah menyelesaikan Tugas Akhir atau yang biasa disebut Skripsi. Mahasiswa yang mengambil mata kuliah Tugas Akhir dapat mengerjakan penelitiannya sesuai dengan bidang keminatan yang diinginkan. Pengelola Tugas Akhir yang sekarang dilakukan masih bersifat manual sehingga proses penyampaian informasi menyita banyak waktu dan tenaga. hal ini memperbesar peluang terjadinya kesalahan dalam penyampaian informasi yang pada akhirnya informasi yang disampaikan menjadi tidak akurat. 
Berikut merupakan flowchart prosedur Tugas Akhir Mahasiswa Teknik Industri Uin Suska Riau:

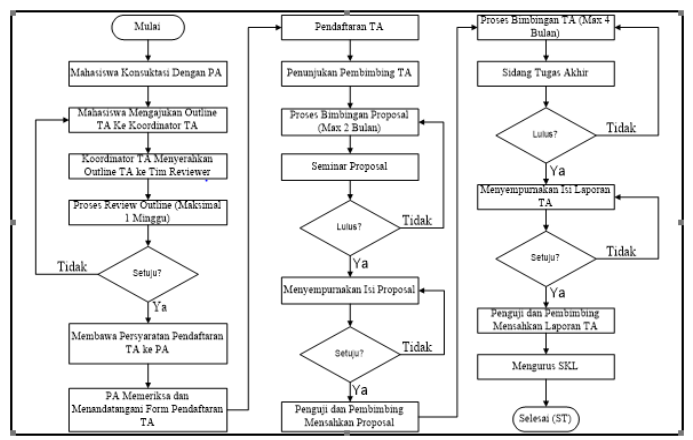

Gambar 1.1 Flowchart Prosedure Tugas Akhir Mahasiswa Teknik Industri

Berdasarkan gambar flowchart diatas yang diperoleh dari Koordinator Tugas Akhir Teknik Industri Uin Suska Riau sarta melakukan observasi dan wawancara mengenai sistem Tugas Akhir Teknik Industri Uin Suska Riau diketahui beberapa permasalahan pada prosedur pengurusan Tugas Akhir tersebut. Pada proses pertama yaitu mahasiswa mengajukan outline TA ke Koordinator TA yang masih dilakukan secara manual dan membutuhkan penggunaan kertas dalam jumlah banyak yang mana mahasiswa harus mencetak outline lalu menyerahkan outline ke Koordinator TA, proses ini menghabiskan waktu kurang lebih setengah hari, pada proses ini pekerjaan menjadi tidak efektif karna dalam proses ini outline bisa diajukan dengan mengupload menggunakan sistem yang pekerjaannya bisa terselesaikan dan juga tidak perlu menggunakan kertas dan juga bisa meminimalisir waktu.

$\begin{array}{cccc}\text { Proses } & \text { kedua yang } & \text { menjadi } \\ \text { permasalahan } & \text { adalah } & \text { pengisian form, }\end{array}$ pencetakan form, mencari tanda tangan PA dan membawa bukti fisik ke Koordinator TA pada saat pengajuan tugas akhir yang mana pada proses prosedur ini memakan waktu lebih kurang 1 hari. Adapun persyaratan pengajuan tugas akhir yang harus dilengkapi pada form ceklis dapat dilihat pada Lampiran A.

Proses ketiga yang menjadi permasalahan adalah penunjukan pembimbing dan penguji TA yang mana koordinator TA harus memberikan informasi penunjukan pembimbing dan penguji TA kepada dosen dan mahasiswa melalui beberapa media sosial yang ada seperti grup dosen dan grup tugas akhir mahasiswa. Proses ini memakan waktu lebih kurang setengah hari yang dapat mengakibatkan pekerjaan tidak efektif dikarnakan dalam proses ini koordinator TA harus mengumumkan informasi secara berulang dan seharusnya informasi ini bisa diumumkan melalui sistem informasi sehingga koordinator TA tidak harus mengirim informasi secara berulang.

Proses yang keempat yang menjadi permasalahan adalah pengajuan seminar proposal yang mana sebelum melakukan seminar proposal mahasiswa harus mendaftar ke Koordinator TA dengan melengkapi, mencetak dan membawa seluruh persyaratan ke koordinator TA yang mana pada prosedur ini memakan waktu kurang lebih 3 hari. Adapun persyaratan pengajuan seminar prooposal yang harus dilengkapi pada form ceklis dapat dilihat pada Lampiran B.

Proses kelima yang menjadi permasalahan adalah pengajuan sidang tugas akhir yang mana sebelum melakukan sidang tugas akhir mahasiswa harus mendaftar ke koordinator TA dengan melengkapi, mencetak dan membawa seluruh persyaratan ke koordinator TA yang mana pada prosedur ini memakan waktu kurang lebih 3 hari. Adapun persyaratan pengajuan sidang tugas akhir yang harus dilengkapi pada form ceklis dapat dilihat pada Lampiran C.

Proses terakhir yang menjadi permasalahan adalah pada saat pengajuan surat keterangan lulus yang mana setelah mahasiswa selesai melaksanakan sidang dan revisi mahasiswa juga harus melengkapi, mencetak, dan membawa seluruh persyaratan ke Koordinator TA untuk mendapatkan surat keterangan lulus yang mana pada pengurusan ini bisa memakan waktu lebih kurang 3 hari. Adapun persyaratan pengajuan surat keterangan lulus yang harus dilengkapi dapat dilihat pada Lampiran D.

\section{Tinjauan Pustaka}

\section{Sistem Informasi}

Menurut O’Brian (2005) sistem informasi (information system) merupakan kombinasi teratur dari orang-orang, perangkat keras (hardware), perangkat lunak (software), jaringan komunikasi, dan sumber daya data yang mengumpulkan, mengubah, dan menyebarkan informasi dalam sebuah organisasi. Orang tergantung pada sistem informasi untuk berkomunikasi antara satu sama lain dengan menggunakan berbagai jenis alat fisik, perintah dan prosedur pemrosesan informasi, saluran telekomunikasi atau jaringan, dan data yang disimpan atau sumber daya data.

$$
\text { Menurut Jogiyanto (1999) sistem }
$$
informasi adalah suatu sistem di dalam suatu 
organisasi yang mempertemukan kebutuhan pengolahan data transaksi harian, mendukung operasi, bersifat manajerial dan kegiatan strategi dari suatu organisasi serta menyediakan pihak luar tertentu dengan laporan-laporan yang diperlukan.

Sistem informasi juga merupakan suatu kumpulan dari komponen-komponen dalam organisasi yang berhubungan dengan proses penciptaan dan aliran informasi. Pada lingkungan berbasis komputer, sistem informasi menggunakan perangkat keras dan lunak komputer, jaringan telekomunikasi, manajemen basis data, dan berbagai bentuk teknologi informasi yang lain dengan tujuan untuk mengubah sumber data menjadi berbagai macam informasi yang dibutuhkan oleh pemakai

\section{Komponen - komponen Sistem Informasi}

Tugas dari sistem informasi adalah untuk melakukan siklus pengolahan data ini. Untuk melakukan sistem ini, maka sebagai suatu sistem diperlukan komponen-komponen tertentu. Telah diketahui bahwa data perlu diolah untuk dijadikan informasi yang bergunan lewat suatu siklus. Siklus ini disebut dengan siklus pengolahan data (data processing life cycle) atau disebut juga dengan nama siklus informasi (information life cycle).

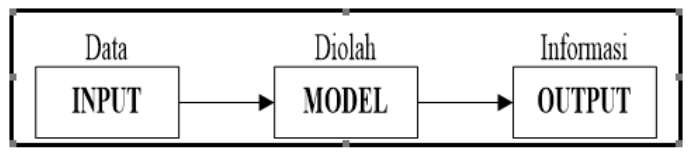

Gambar 2.2 Siklus Pengolahan Data

Dari gambar diatas terlihat, bahwa untuk melakukan siklus pengolahan data diperlukan tiga buah kompone yaitu komponen input, komponen model dan komponen output. Dengan demikian, sistem informasi yang juga melakukan proses pengolahan data juga akan membutuhkan tiga komponen ini.

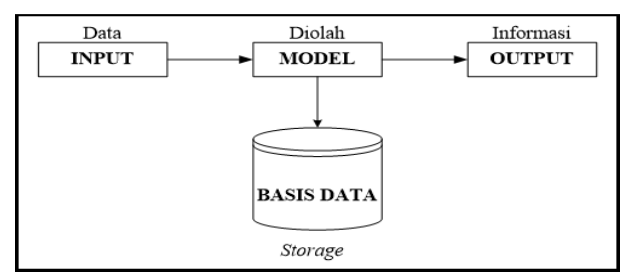

Gambar 2.3 Siklus pengolahan data yang dikembangkan

Dari siklus data yang dikembangkan, terlihat bahwa untuk melakukan pengolahan data, maka diperlukan tambahan sebuah komponen lagi, yaitu komponen basis data. Dengan demikian, komponen-komponen sistem informasi yaitu komponen input, komponen model dan komponen output sekarang bertambah sebuah komponen lagi, yaitu komponen basis data.

Pertanyaannya sekarang adalah apakan keempat komponen ini telah cukup membentuk suatu sistem informasi untuk mencapai tujuannya. Untuk menjawab pertanyaan ini, maka perlu diuji apakah tujuan dari sistem informasi, yaitu menghasilkan informasi yang berguna dapat dicapai. Informasi yang relevan (relevance) dapat dicapai dengan komponen tersebut.

\section{Langkah - langkah Pembuatan Sistem Informasi}

Berikut adalah tahapan-tahapan dalam pembuatan Sistem Informasi:

1. Deskripsi Alur Sistem

Langkah awal dalam tahap analisis sistem adalah dengan melakukan identifikasi masalah. Idenfitikasi masalah dilakukan dengan pengidentifikasian kendala atau permasalahan yang ada.

2. Deskripsi Alur Sistem Usulan

Tujuan utama dari perancangan sistem secara umum adalah memberikan gambaran tentang sistem yang akan dibangun serta memahami alur informasi dan proses yang ada dalam sistem.

3. Data Flow Diagram

Data Flow Diagram (DFD) adalah sebuah alat yang menggambarkan aliran data sampai sebuah sistem selesai dan kerja atau proses dilakukan dalam sistem tersebut. Istilah dalam bahasa Indonesianya adalah Diagram Aliran Data. Data Flow Diagram adalah suatu model logika data atau proses yang dibuat lebih mendetail dibanding diagram konteks yang diperbolehkan, bisa dicapai dengan mengembangkan diagram. Sisa diagram asli dikembangkan ke dalam gambaran yang lebih terperinci yang melibatkan tiga sampai sembilan proses dan menunjukkan penyimpanan data dan aliran data baru pada level yang lebih rendah.

4. Pembuatan E-R Diagram

Entity relationship Model merupakan suatu model data yang dikembangkan berdasarkan objek. ER_M digunakan uuntuk menjelaskan hubungan antar data dalam basis data kepada pemakai secara logik. ER_M didasarkan pada suatu presepsi bahwa real word terdiri atas obyek-obyek dasar yang mempunyai hubungan/kerelasian antar obyek-obyek dasar tersebut. ER_M digambarkan dalam bentuk diagram yang disebut diagram ER ( ER_Diagram/ER_D )dengan menggunakan 
simbol-simbol grafis tertentu. Model ini juga membantu perancang basis data dalam melakukan analisis dan perancangan basis data karena model ini dapat menunjukan macam data yang dibutuhkan dan kerelasian antar data didalamanya.

5. Pembuatan Relasi Database

Basis data (database) merupakan kumpulan data yang saling berhubungan (punya relasi). Relasi biasanya ditunjukkan dengan kunci (key) dari tiap file yang ada. Dalam satu file terdapat record-record yang sejenis, sama besar, sama bentuk, yang merupakan satu kumpulan entitas yang seragam. Satu record terdiri dari field-field yang saling berhubungan dan menunjukkan dalam satu pengertian yang lengkap dalam satu record.

6. Perancangan Aplikasi Antar Muka

Antar-muka adalah suatu sistem bagi kebanyakan pengguna. Bagaimanapun bagus atau buruknya rancangannya, antar-muka tersebut menjadi gambaran dari sistem dan sebagai bayangan dari kompetensi anda sebagai seorang penganalisis sistem.

7. Pembuatan Aplikasi Web

Pada pembuatan aplikasi ini proses yang akan dilakukan adalah Membuat dan menjalankan aplikasi pada server localhost sampai ke tahap menghosting melalui webhosting.

\section{Ergonomi}

Istilah ergonomi berasal dari bahasa Yunani yang terdiri dua kata yaitu "ergon" berarti kerja dan "nomos" berarti aturan atau hukum. Jadi secara ringkas ergonomi adalah suatu aturan atau norma dalam sistem kerja. Di Indonesia memakai istilah ergonomi, tetapi di beberapa negara seperti di Skandinavia menggunakan istilah "Bioteknologi" sedangkan di negara Amerika menggunakan istilah "Human Engineering" atau "Human Factors Engineering". Namun demikian, kesemuanya membahas hal yang sama yaitu tentang optimalisasi fungsi manusia terhadap aktivitas yang dilakukan. Dari pengalaman menunjukkan bahwa setiap aktivitas atau pekerjaan yang dilakukan, apabila tidak dilakukan secara ergonomis akan mengakibatkan ketidaknyamanan, biaya tinggi, kecelakaan dan penyakit akibat kerja meningkat, performansi menurun yang berakibat kepada penurunan efisiensi dan daya kerja. Dengan demikian, penerapan ergonomi di segala bidang kegiatan adalah suatu keharusan.

\section{Display}

Display merupakan bagian dari lingkungan yang perlu memberi informasi kepada pekerja agar tugas-tugasnya menjadi lancar. Arti informasi disini cukup luas, menyangkut semua rangsangan yang diterima oleh indera manusia baik langsung maupun tidak langsung.

\section{Aturan Huruf Dalam Merancang Display}

Dimensi huruf ditentukan agar display berfungsi sebagai penyempai informasi yang baik. Kita dapat menentukan dimensi yang ideal dari jarak yang kita inginkan. Dengan menggunakan rumus sebagai berikut:

Tinggi huruf atau angka $=$ $\frac{\text { Jarak Visual }(\mathrm{mm})}{200}$

Tabel 2.1 Ukuran Perbandingan dan Jarak Huruf

\begin{tabular}{|c|c|c|c|}
\hline Huruf & $\begin{array}{c}\text { Perbandi } \\
\text { ngan }\end{array}$ & $\begin{array}{c}\text { Warn } \\
\text { a } \\
\text { Latar }\end{array}$ & $\begin{array}{c}\text { Jarak } \\
\text { Terjau } \\
\text { h Dapat } \\
\text { dilihat }\end{array}$ \\
\hline Putih & Hitam & $\begin{array}{c}1: \\
13,3\end{array}$ & $\begin{array}{c}36,5 \\
\text { Meter }\end{array}$ \\
\hline Hitam & Putih & $1: 8$ & $\begin{array}{c}33,5 \\
\text { Meter }\end{array}$ \\
\hline
\end{tabular}

Tinggi huruf kecil $(\mathrm{h})=\frac{2}{3} \times \mathrm{H}(2.2)$

Lebar huruf besar $=\frac{2}{3} \times \mathrm{H}(2.3)$

Lebar huruf kecil $(\mathrm{h})=\frac{2}{3} \times \mathrm{h}(2.4)$

Tebal huruf besar $=\frac{1}{6} \times \mathrm{H}(2.5)$

Tebal huruf kecil $=\frac{1}{6} \times \mathrm{h}(2.6)$

Jarak antara 2 huruf $=\frac{1}{4} \times \mathrm{H}(2.7)$

Jarak antara dua angka $=\frac{1}{5} \times \mathrm{H}(2.8)$

Jarak antara huruf dan angka $=\frac{1}{5} \times \mathrm{H}(2.9)$

Jarak antara $2 \mathrm{kata}=\frac{2}{3} \times \mathrm{H}(2.10)$

Jarak antara baris antar kalimat $=\frac{2}{3} \times \mathrm{H}(2.11)$

\section{Psikologi Warna}

Kita perlu menyadari bahwa warna bukanlah merupakan suatu besaran fisik. Warna merupakan suatu sensasi yang dihubungkan dengan sistem syaraf kita, seperti hal nya rasa maupun bau. Sensasi warna diperoleh dengan adanya interaksi antar warna kita. Lensa pada mata manusia tidak mempunyai kemampuan untuk mengoreksi warna. Hal ini menimbulkan suatu efek yang disebut dengan kromosstereopsis, yakni efek yang 
menyebabkan warna-warna murni pada jarak yang sama terlihat mempunyai jarak yang berbeda. Pada kebanyakan kita manusia, warna merah biasanya cendrung mempunyai jarak paling dekat, sementara warna biru cenderung mempunyai jarak paling jauh.

Para ahli menunjukkan bahwa secara praktis pengalaman biasanya tidak linear terhadap kejadian fisik. Hubungan ini hampir mendekati fungsi logaritmik, dengan persepsi kecerahan akan meningkat secara logaritmis terhadap intensitas ransangan. Cahaya putih berisi semua panjang gelombang yang dapat ditanggapi oleh manusia. Jika cahaya seperti ini mengenai objek dan semua komponen cahaya dipantulkan secara merata, warna obyek adalah akromatik. Sehingga, obyek akan muncul dengan warna putih, hitam, atau aras abu. Obyek yang memantulkan cahaya putih dengan distribusi yang tidak merata pada panjang gelombang yang ada akan menyebabkan timbulnya efek kromatik, sehingga benda terlihat mempunyai warna tertentu.

\section{Metodologi Penelitian}

Metodologi penelitian merupakan tahapan-tahapan yang dilalui peneliti mulai dari pengumpulan data sampai dengan penarikan kesimpulan yang membentuk sebuah alur yang sistematis. Tahapan penelitian dipaparkan pada flowchart dibawah ini:

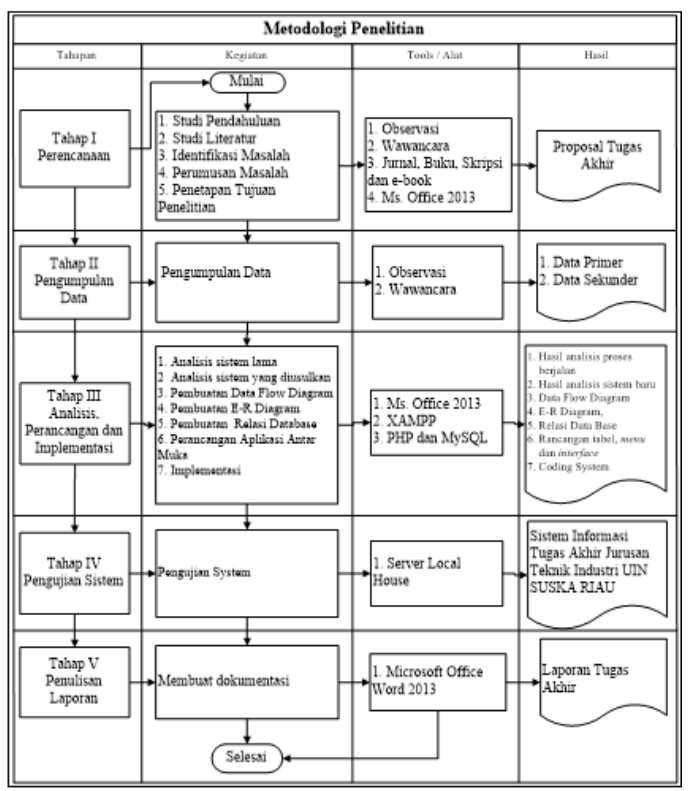

Gambar 1. Flowchart Penelitian

Hasil dan Pembahasan

\section{Evaluasi Sistem Lama}

Prosedur pengurusan tugas akhir dijurusan teknik industri Universitas islam negeri sultan syarif kasim riau masih menggunakan sistem pengurusan prosedur yang manual sehingga membuat suatu pekerjaan menjadi tidak efektif dan efisien. Pada proses pengajuan outline, pengajuan tugas akhir, pengajuan seminar proposal, pengajuan sidang tugas akhir, pengajuan surat keterangan lulus, mahasiswa harus melengkapi beberapa persyaratan serta mencetak beberapa file sehingga membutuhkan kertas yang banyak dan selain itu mahasiswa juga harus mencari tanda tangan untuk melengkapi persyaratan tersebut. Selain mahasiswa, koordinator TA juga harus memberikan infomasi penunjukan pembimbing dan penguji secara berulang yaitu kepada dosen dan juga ke mahasiswa yang mengambil mata kuliah tugas akhir. Proses pengurusan tugas akhir yang ada dijurusan teknik industri Universitas islam negeri sultan syarif kasim riau pada saat sekarang ini memiliki resiko dalam segi penyimpanan data base mahasiswa.

Pada saat ini, penyebab permasalahan prosedur pengurusan tugas akhir dijurusan teknik industri adalah masih belum adanya suatu sistem yang bisa menangani segala permasalahan prosedur tugas akhir. Oleh karena itu, jurusan teknik industri saat ini sangat memerlukan sebuah sistem untuk menangi hal tersebut demi membantu kebutuhan jurusan dalam akreditasi dan dalam kebutuhan database jurusan. Prosedur pegurusan tugas akhir pada saat ini mempunyai kekurangan disana sini sehingga membuat proses pengurusan menjadi lama dan juga berbelit-belit. Akan tetapi dari sisi lainnya, pengurusan tugas akhir yang ada saat ini terlihat bagus karena berkas dapat dilihat dalam keadaan apapun dan lebih transparan. Maka dari itu, permasalahan ini harus diselesaikan karena akan mengganggu kinerja koordinator TA dan terhambatnya mahasiswa dalam mengerjakan tugas akhir, karena harus melengkapi beberapa persyaratan yang cukup banyak. Selain itu tuntutan kemajuan era globalisasi saat ini yang sudah berbasis teknologi, segala pengurusan prosedur mengharuskan adanya suatu pengerjaan yang efektif dan efisien, maka dari itu untuk mengatasi permasalahan tugas akhir yang ada pada saat ini dijurusan teknik industri universitas islam negeri sultan syarif kasim riau, dirancanglah sebuah aplikasi sistem informasi untuk mengatasi permasalahan tugas akhir saat ini.

\section{Penerapan Sistem Usulan}

Pada sistem usulan ini lebih memudahkan mahasiswa dalam mengejarkan 
prosedur pengurusan tugas akhir karena, segala pengurusan tugas akhir sudah bisa diakses secara online. Selain itu, Sistem informasi ini juga bermanfaat bagi mahasiswa karena segala persyaratan tidak harus lagi dicetak tetapi sudah bisa diupload melalui sistem informasi. Pada sistem informasi, informasi tugas akhir yang akurat bisa didapat dengan mudah oleh mahasiswa karena informasi tersebut diberitahukan oleh koordinator TA secara langsung melalui sistem informasi. Sistem informasi juga sangat membantu koordinator dalam menyimpan database mahasiswa dengan baik karena, segala database sudah berbasis teknologi. Selain itu, pada sistem informasi usulan ini mahasiswa juga mendapatkan id untuk bisa login sehingga selain mudah diakses sistem ini juga mempunyai keamanan untuk database tugas akhir. Akan tetapi, dari sisi lainnya sistem usulan ini masih tahap awal dan mempunyai kelemahan karena, yang bisa mengakses sistem usulan ini hanya koordinator dan mahasiswa. Selain itu sistem ini juga belum memenuhi kebutuhan seutuhnya karena sistem ini belum sesuai kebutuhan yang diharapkan. Pada perancangan Sistem Informasi ini menggunakan beberapa aturan yang mengatur tentang display agar tampilan yang ada pada sistem informasi tugas akhir ini dapat menyampaikan informasi yang bisa diterima dengan baik oleh pengguna yaitu, koordinator dan mahasiswa sehingga tampilan yang ada mudah dimengerti oleh pengguna. Selain itu, warna yang ada pada tampilan juga membuat pengguna nyaman menggunakannya karena, warna yang dibuat sudah disesuaikan dengan aturan display sehingga tidak membuat mata sakit. Ukuran huruf yang digunakan juga berbeda-beda sesuai dengan kegunaannya.

\section{Context Diagram}

Context diagram digunakan untuk menggambarkan proses kerja sistem secara umum. Context diagram merupakan Data Flow Diagram yang menggambarkan garis besar operasional sistem, bisa dilihatkan pada gambar 4.1.

\section{Pembuatan Data Flow Diagram (DFD)}

Data Flow Diagram (DFD) sering digunakan untuk menggunakan suatu sistem yang telah ada atau sistem baru yang akan dikembangkan secara logika tanpa mempertimbangkan lingkungan fisik dimana data tersebut mengalir, atau lingkungan fisik dimana data tersebut tersimpan.

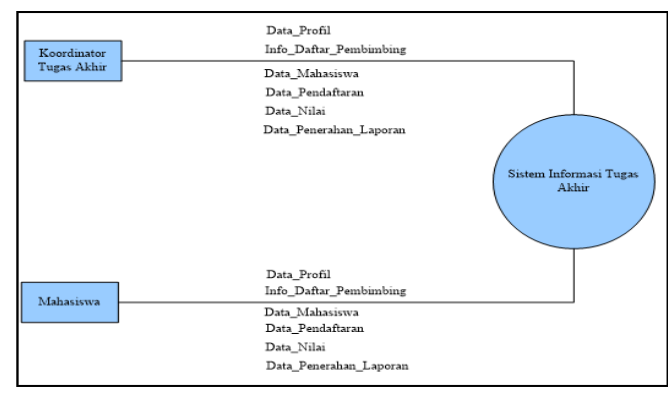

Gambar 4.1 Context Diagram

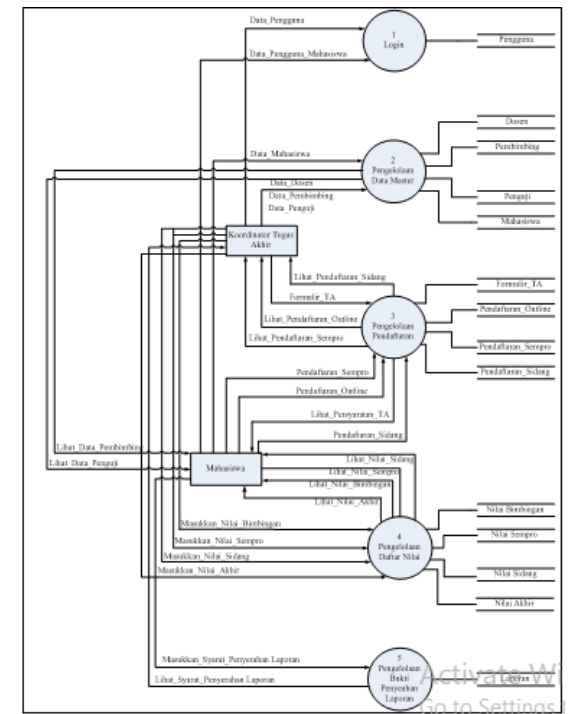

Gambar 4.2 Data Flow Diagram Level 1

\section{Entity Realtional Diagram (ERD)}

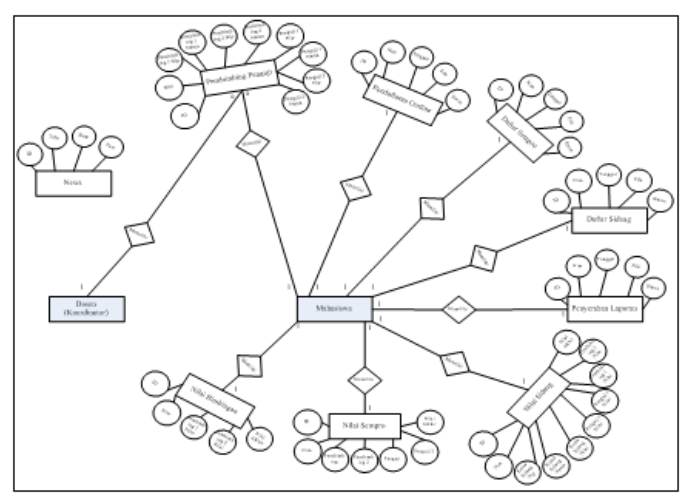

Gambar 4.7 Entity Realtional Diagram

\section{Perancangan Struktur Menu Sistem}

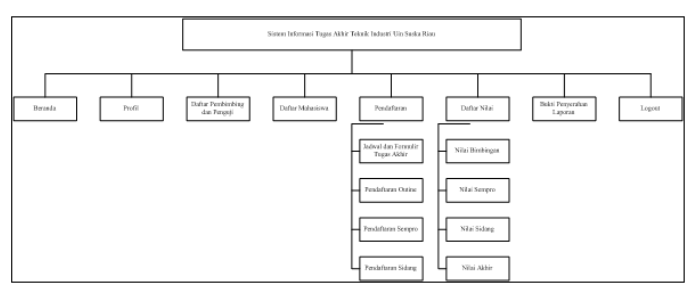

Gambar 4.9 Perancangan Struktur Menu Sistem 


\section{Perancangan Antar Muka}

Interface sistem merupakan sebuah sarana pengembangan sistem yang digunakan untuk membuat komunikasi dan penyampaian informasi lebih mudah, konsistensi antara sistem dengan User, Interface, meliputi tampilan yang lebih baik, mudah dipahami dan tombol-tombol yang familiar dan Friendly.

\section{Rancangan Menu Login}

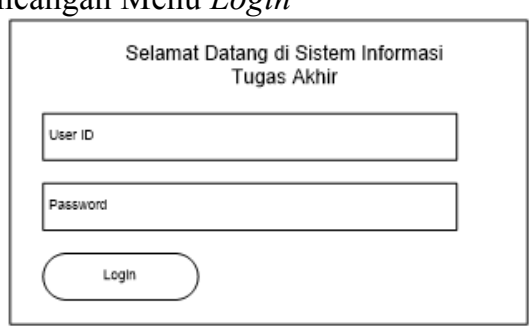

Gambar 4.10 Perancangan Login

2. Rancangan Menu Tampilan Koordinator

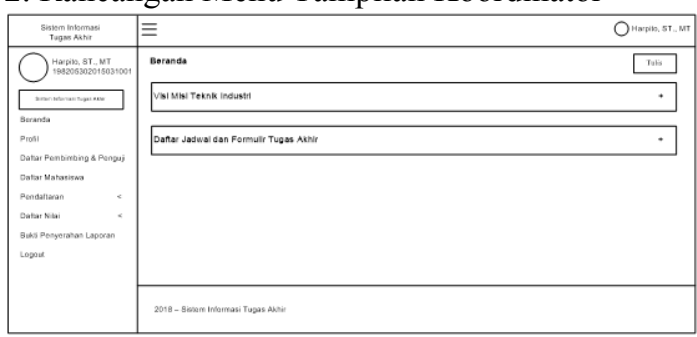

Gambar 4.11 Tampilan Menu Koordinator

3. Rancangan Menu Tampilan Mahasiswa

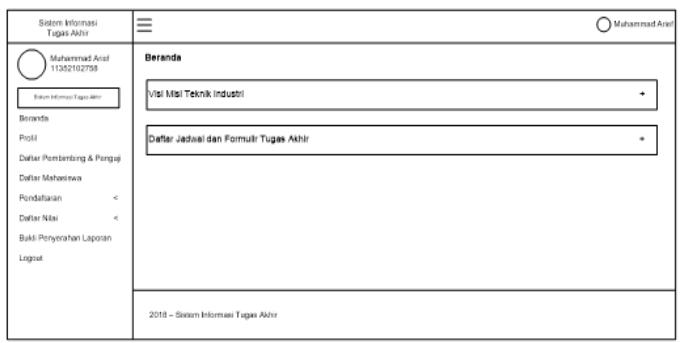

Gambar 4.24 Tampilan Menu Mahasiswa

\section{Perencanaan Display (Display Planning)}

Perencanaan dislay merupakan langkah untuk merancang dan membuat tampilan display sistem informasi tugas akhir jurusan teknik industri universitas islam negri sultan syarif kasim riau. Pada perencanaan display ini kita akan menentukan ukuran huruf dan pemilihan warna yang sesuai dengan aturan display.

\section{Pemilihan Warna}

Warna yang digunakan pada tampilan sistem informasi tugas akhir jurusan teknik industri universitas islam negri sultan syarif kasim riau ini menggunakan dua kategori warna yaitu warna dasar dan warna pendukung yang mana warna dasar merupakan warna yang mendasari dari desain sistem tersebut sedangkan warna pendukung adalah warna yang mendukung agar tampilan desain tesebut menarik dan enak dilihat. Tampilan login pada sistem informasi menggunakan warna dasar hijau dan abu-abu sedangkan warna pendukung pada tampilan login menggunakan warna putih. Tampilan menu pada sistem informasi menggunakan warna dasar biru dan abu-abu sedangkan warna pendukung pada tampilan menu ini menggunakan warna hitam dan putih.

\section{Ukuran Huruf}

Ketajaman pandangan atau visual acuity perlu diperhatikan agar figur display atau informasi yang dirancang dapat dipahami secara jelas dan baik oleh pembaca atau yang melihatnya. Pada perancangan sistem informasi tugas akhir jurusan teknik industri universitas islam negri sultan syarif kasim riau menggunakan empat jenis ukuran huruf atau Font yaitu 20, 18, 16 dan 13.

1. Perhitungan Ukuran Huruf / Angka Font 20 Pada ukuran huruf pada Font 20 ini kita akan menggunakan jarak pandang $60 \mathrm{Cm}=600 \mathrm{~mm}$.

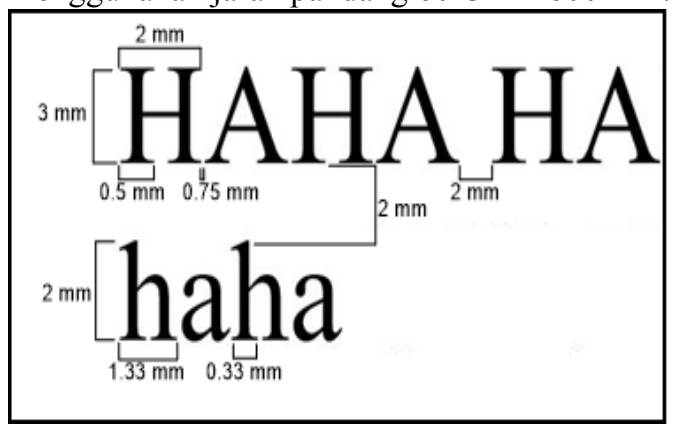

Gambar 4.37 Ukuran Huruf pada Font 20

2.Perhitungan Ukuran Huruf/Angka Font 18

Pada ukuran huruf pada Font 18 ini kita akan menggunakan jarak pandang $60 \mathrm{Cm}=600$ $\mathrm{mm}$.

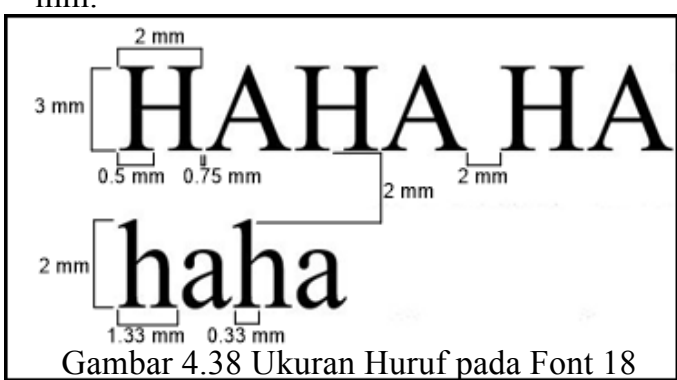

3. Perhitungan Ukuran Huruf / Angka Font 16

Pada ukuran huruf pada Font 16 ini kita akan menggunakan jarak pandang $50 \mathrm{Cm}=500 \mathrm{~mm}$. 


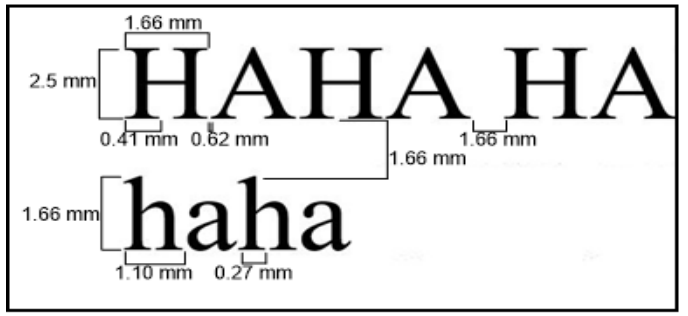

4.Perhitungan Ukuran Huruf / Angka Font 13 Pada ukuran huruf pada Font 13 ini kita akan menggunakan jarak pandang $45 \mathrm{Cm}=450 \mathrm{~mm}$.

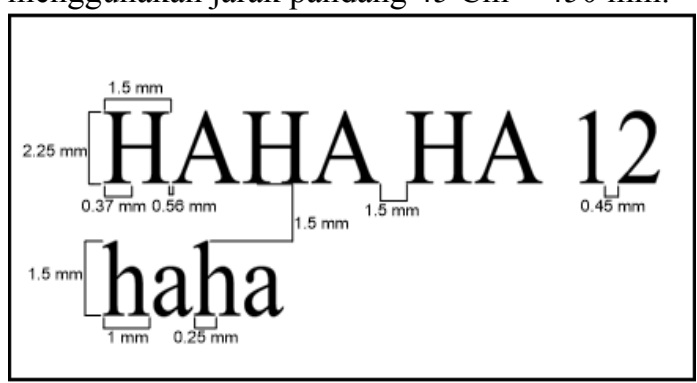

Gambar 4.40 Ukuran Huruf pada Font 13

\section{Implementasi}

Implementasi merupakan tahap pembuatan sistem berdasarkan hasil perancangan yang telah didesain sebelumnya hingga sistem dapat difungsikan dalam keadaan sebenarnya dan dapat diketahui apakah sistem yang dibuat berhasil mencapai tujuan yang sebenarnya. Adapun tujuan implementasi adalah sebagai berikut:

1. Membuat dan memastikan sistem informasi yang dibuat telah sesuai dengan kebutuhan atau permintaan pengguna berdasarkan analisa dan perancangan yang telah dilakukan

2. Memastikan pengguna dapat menjalankan sistem berdasarkan pelatihan dan prosedur penggunaan sistem tersebut

\section{Halaman Login}

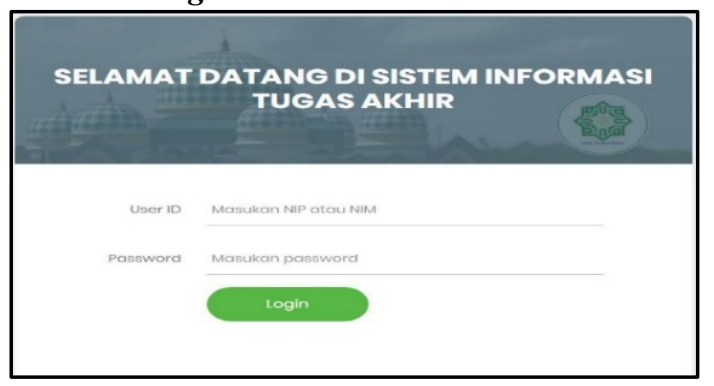

Gambar 4.41 Halaman Login

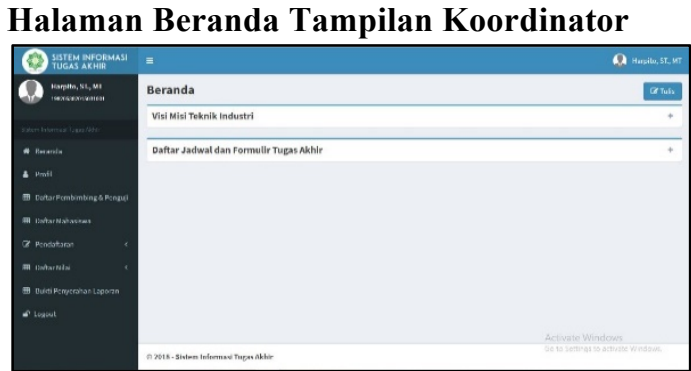

Gambar 4.42 Tampilan Beranda Koordinator

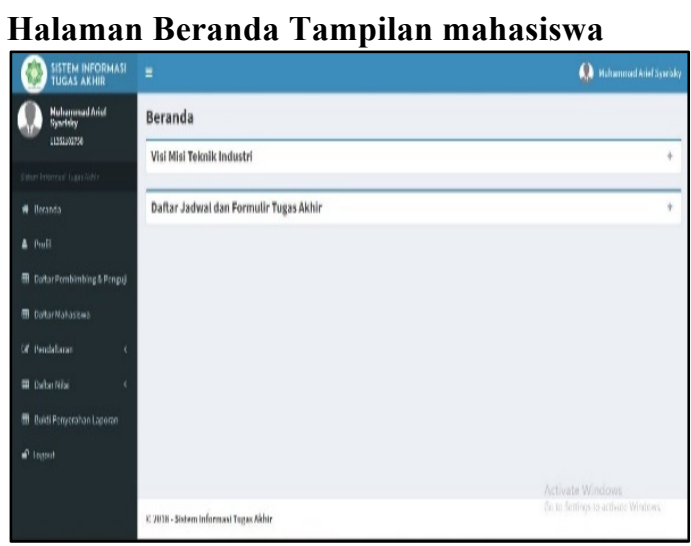

Gambar 4.55 Tampilan Beranda Mahasiswa

\section{Pengujian sistem}

Adapun kriteria pengujian sistem tersebut dimaksudkan untuk mengetahui kebenaran dari sistem tersebut dan kesesuaian dengan spesifikasinya dinyatakan berhasil jika sistem informasi ini mampu menjalankan fungsi-fungsi berdasarkan spesifikasi secara benar. Pengujian sistem informasi tugas akhir jurusan teknik industri universitas islam negri sultan syarif kasim riau ini dipercobakan atau diuji oleh 30 orang mahasiswa yang mengambil tugas akhir dengan cara melakukan percobaan serta mengoperasikan sistem informasi tugas akhir jurusan teknik industri universitas islam negri sultan syarif kasim riau. 


\begin{tabular}{|c|c|c|c|c|c|c|}
\hline \multirow{2}{*}{ No } & \multirow{2}{*}{ Pernyataan } & STS & TS & KS & $\mathbf{S}$ & SS \\
\hline & & 1 & 2 & 3 & 4 & 5 \\
\hline 1 & $\begin{array}{l}\text { Informasi yang disediakan pada sistem informasi tugas akhir } \\
\text { ini mudah dimengerti }\end{array}$ & - & - & - & $56 \%$ & $80 \%$ \\
\hline 2 & $\begin{array}{l}\text { Penggunaan menu atau fitur menu sistem informasi tugas } \\
\text { akhir mudah digunakan }\end{array}$ & - & - & - & $76 \%$ & $55 \%$ \\
\hline 3 & $\begin{array}{l}\text { Sistem informasi tugas akhir sudah sesuai kebutuhan untuk } \\
\text { tugas akhir }\end{array}$ & - & $10 \%$ & $30 \%$ & $28 \%$ & $40 \%$ \\
\hline 4 & Sistem informasi tugas akhir dapat mudah untuk dipelajari & - & - & $33 \%$ & $80 \%$ & $45 \%$ \\
\hline 5 & Sistem informasi tugas akhir mudah dioperasikan & - & - & - & $64 \%$ & $70 \%$ \\
\hline 6 & Sistem informasi tugas akhir bermanfaat bagi mahasiswa & - & - & - & $20 \%$ & $125 \%$ \\
\hline 7 & Tampilan menu dalam sistem informasi mudah dikenali & - & - & $3 \%$ & $72 \%$ & $55 \%$ \\
\hline 8 & Mempunyai kemampuan dan fungsi sesuai yang diharapkan & - & $2 \%$ & $12 \%$ & $60 \%$ & $50 \%$ \\
\hline 9 & $\begin{array}{l}\text { Warna yang digunakan di sistem informasi tugas akhir enak } \\
\text { dilihat }\end{array}$ & - & - & - & $28 \%$ & $115 \%$ \\
\hline 10 & Meminimalisir kesalahan pada formulir tugas akhir & - & $2 \%$ & $24 \%$ & $68 \%$ & $20 \%$ \\
\hline 11 & Memudahkan dalam pengurusan prosedur tugas akhir & - & - & $15 \%$ & $84 \%$ & $20 \%$ \\
\hline 12 & Mudah mendapatkan informasi tentang tugas akhir & - & - & - & $44 \%$ & $95 \%$ \\
\hline 13 & $\begin{array}{l}\text { Sistem informasi tugas akhir membuat mahasiswa } \\
\text { Mendapatkan informasi yang akurat }\end{array}$ & - & - & - & $36 \%$ & $105 \%$ \\
\hline 14 & Mengurangi menggunakan penggunaan kertas & - & - & - & $72 \%$ & $55 \%$ \\
\hline 15 & Meminimalisir waktu untuk pengurusan prosedur tugas akhir & - & - & - & $52 \%$ & $60 \%$ \\
\hline
\end{tabular}

Dari pernyataan diatas rata-rata mahasiswa menduung dengan adanya sistem informasi ini, namun ada beberapa item yang masih harus diperbaiki sesuai dari pernyataan mahasiswa seperti pernyataan nomor 3 terhadap Sistem informasi tugas akhir sudah sesuai kebutuhan untuk tugas akhir, nomor 8 Mempunyai kemampuan dan fungsi sesuai yang diharapkan dan nomor 10 Meminimalisir kesalahan pada formulir tugas akhir.

\section{Kesimpulan}

Setelah dilakukan pengolahan, perancangan dan analisa data dapat dimabil kesimpulan bahwasanya sistem yang dihasilkan adalah sistem informasi tugas akhir jurusan teknik industri, dan perancangan sistem informasi tugas akhir ini menggunakan software XAMPP v3.2.1. Dalam perancangan ini terdapat 2 data flow diagram yaitu sampai Level 2 dimana user untuk tahap ini yang bisa mengakses Sistem Informasi ini hanya Koordinator TA dan Mahasiswa. Setelah melakukan perancangan serta melakukan pengujian sistem maka sistem usulan proses pengurusan tugas akhir ini layak diimplementsikan karena permasalahan yang ada pada prosedur pengurusan tugas akhir sebelumnya sudah terjawab dengan sistem informasi yang sudah dirancang.

\section{Daftar Pustaka}

[1] Abdurrahmmah, "Perancangan Display Ergonomis Di.PT Perindustrian dan Perdagangan Bangkinang Pada Lantai Produksi". Tugas Akhir. Universitas Negeri Sultan Syarif Kasim Riau, Pekanbaru, 2016.

[2] Isa, Ahmad Robiul, "Perancanga Sistem Penjualan buku berbasis Website". Naskah Publikasi Sekolah Tinggi Manajemen Informatika dan Komputer. Amikom Yogyakarta, Yogyakarta, 2016.

[3] Jogiyanton, "Sistem Teknologi Informasi". ANDI, Yogyakarta, 2005.

[4] Kendall E Kenneth., Julie E Kendall, "Analisis Dan Perancangan Sistem". PT. Indeks Kelompok Gramedia, Jakarta, 2002. 
[5] Kholil, Ishak, "Modul PHP Web Programing". Akademi Manajemen Informatika dan Komputer Bina Sarana Informatika, Jakarta, 2006

[6] Kusumawati, Tyas dkk, "Pembuatan Sistem Informasi Akademik Pada Sekolah Menengah Atas Negeri 2 Pacitan”. ISSN: 2302-5700, Pacitan, 2013.

[7] Mujahidin, "Perancangan Visual Display Kuantitatif Pada Sistem Menusia Mesin". Optimum Vol. 1 No. 1. Jurusan Teknik Industri Fakultas Teknik Institut Teknologi Nopember, Surabaya, 2000.

[8] Noviardy, Syeni, "Perancanga Sistem Informasi Kesehatan Berbasis Web". Tugas Akhir. Akademi Manajemen Informatika dan Komputer Bina Sarana Informatika, Jakarta, 2013.

[9] Nur Heri Cahyana dkk, "Aplikasi Penerimaan Siswa Baru Berbasis Web". Telematika Vol. 10, No.1. Universitas Pembangunan Nasional "Veteran", Yogyakarta, 2013.

[10] Purnomo, Wahyu, "Pemograman Web Semester 1". Kementrian Pendidikan dan Kebudayaan, Malang 2013

[11] Putra, Riosaka, "Aplikasi Penjualan Berbasis Web Pada PT. Pratapa Nirmala Palembang". Tugas Akhhir. Jurusan Komputerisasi Akuntansi STMIK GI MDP, Palembang, 2012

[12] Respanti, Harianto, "Pengendalian Teknologi Informasi Bank Pada Era Cyber Banking”. Jurnal Ekonomi MODERNISASI Volume 4 Nomor 3 Fakultas Ekonomi Universitas Kanjuruhan, Malang, 2008.

[13] Risky Shelia Fathia, Evayani, "Analisis dan Perancangan Sistem Informasi Akuntansi Berbasis Data Pada Sistem Persediaan dan Penjualan". Jurnal Ilmiah Vol. 1, No. 2. Universitas Syiah Kuala, Aceh, 2016.

[14] Santosa, Insap, "Interaksi Manusia \& Komputer”. ANDI. Yogyakarta, 2004.
[15] Samodera, Adi Akhmad, "Sistem Informasi Penjualan Pada Kokikuen Toko Komputer Berbasis Web”. Jurnal Sekolah Tinggi Manajemen Informatika dan Komputer. Amikom Purwokerto, Purwekerto, 2014

[16] Saputra Sandra dkk, "Perancangan Sistem Informasi Tugas Akhir II Program Studi Teknik Industri UPN "Veteran" Berbasis Web". Tugas Akhir. Universitas Pembanguna "Veteran", Yogyakarta, 2014.

[17] Sritomo Wignjosoebroto dkk, "Perancangan Interface Prototype Web Berdasarkan Pada Aspek Usability". Jurnal. Institut Teknologi Sepuluh November, Surabaya, 2008.

[18] Sulistiyani, Sri, "Keamanan Sistem Informasi”. CV. ANDI, Yogyakarta, 2011.

[19] Tarwaka dkk, "Ergonomic Untuk Keselamatan, Kesehatan Kerja dan Produktivitas". Cetakan Pertama UNIBA PRESS, Surakarta, 2004.

[20] Wignjosoebroto, Sritomo, “Analisis Ergonomi Terhadap Rancangan Fasilitas Kerja Pada Stasiun Kerja di Bagian Skiving dengan Antropometri Orang Indonesia”. Jurnal. Fakultas Teknologi Industri ITS, Surabaya, 2007.

[21] Yakub, "Pengantar Sistem Informasi". Cetakan Pertama GRAHA ILMU, Yogyakarta, 2012 